\title{
The Document: Low-Relief Comforter
}

Carol Itter
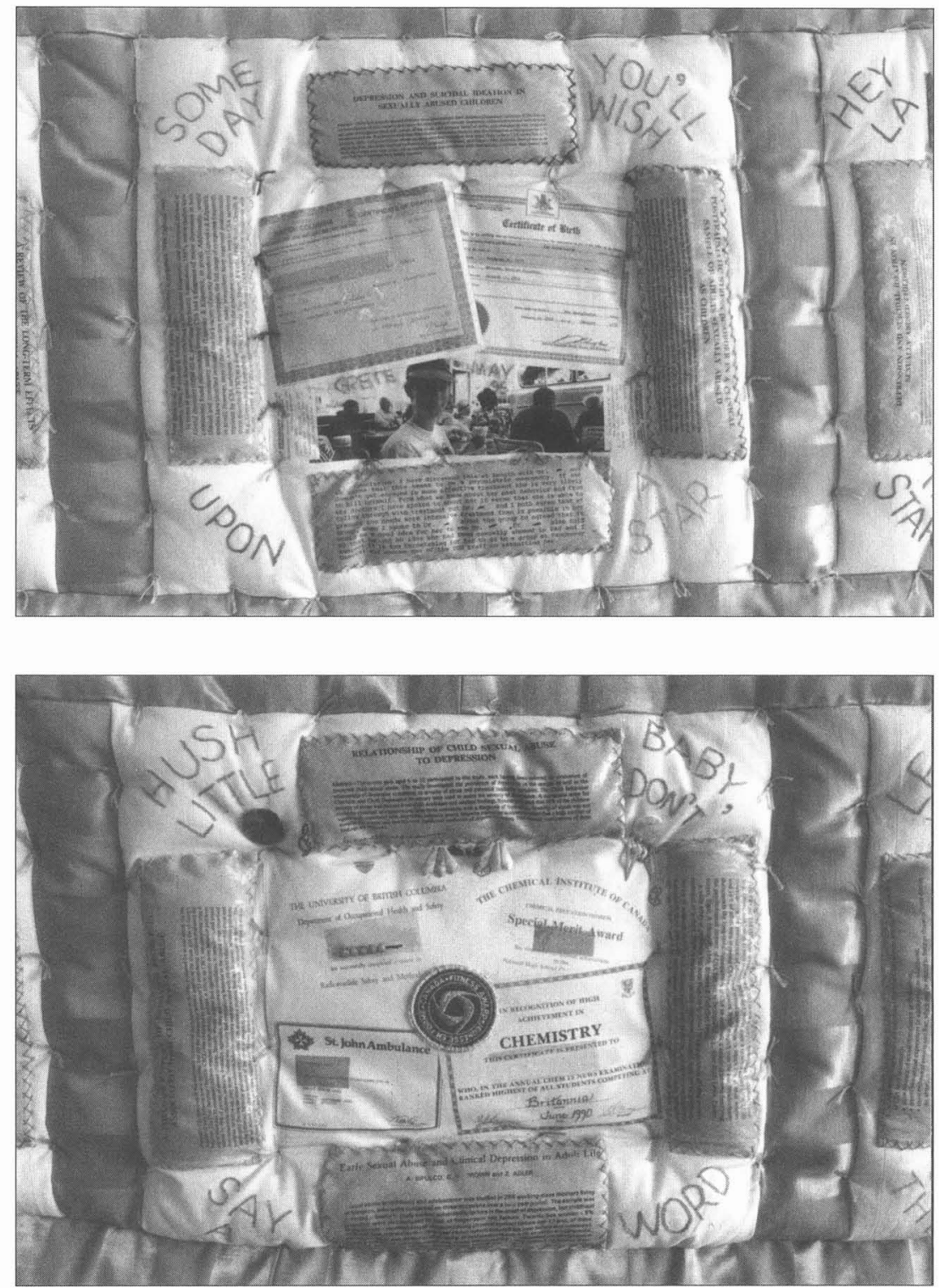

two of nine panels, detail $20^{\prime \prime} \times 22$," complete comforter approx. $82^{\prime \prime} \times 80^{\prime \prime}$ 